\title{
ANALISIS PENERAPAN STANDAR AKUNTANSI DAN SISTIM PENGENDALIAN INTERNAL TERHADAP KUALITAS LAPORAN KEUANGAN
}

\author{
Alwi \\ Sekolah Tinggi Ilmu Ekonomi (STIE) Bima \\ Email: alwi_muhammad1317@yahoo.co.id \\ M. Rimawan \\ Sekolah Tinggi Ilmu Ekonomi (STIE) Bima \\ Email: Rimawan111@gmail.com \\ Aliah Pratiwi \\ Sekolah Tinggi Ilmu Ekonomi (STIE) Bima \\ Email: aliahpratiwi@ymail.com
}

\begin{abstract}
This study aims to analyze the effect of the adoption of Government Accounting Standards and Internal Control Systems on the Quality of Financial Statements of case studies conducted at the Regional Government Work Unit in Bima City Government. The research instrument used was a questionnaire with a Likert scale. The population and sample in this study is the Regional Work Unit as an accounting entity in the Bima City government area. The sampling method in this study uses a purposive sampling method with the Quota Sampling approach with each SKPD there are 3 respondents sampled namely the Head of Finance, Section Head as reviewer of the financial statements that have been prepared and Accounting Section Staff in charge of directly compiling financial statements. Data analysis techniques used in this study are the Validity Test, Reliability Test, Classical Assumption Test (Normality, Multicollinearity, Autokoerlasi) and Hypothesis Test with Multiple Linear Regression Test. The results of the analysis conducted in this study indicate that there is a positive influence on the application of Government Accounting Standards and Internal Control Systems to the Quality of Financial Statements in the Regional Government Work Unit of the City of Bima.
\end{abstract}

Keywords: Government Accounting Standards, Internal Control System, Quality of Financial Statements.

\begin{abstract}
Abstrak
Penelitian ini bertujuan untuk menganalisa pengaruh penerapan Standar Akuntansi Pemerintah dan Sistim Pengendalian Internal terhadap Kualitas Laporan Keuangan studi kasus dilakukan pada Satuan Kerja Perangkat Daerah di Pemerintahan Kota Bima. Instrumen penelitian yang digunakan adalah Kuesioner dengan skala Likert. Populasi dan sampel dalam penelitian adalah Satuan Kerja Perangkat Daerah sebagai entitas akuntansi di wilayah pemerintahan Kota Bima. Metode pengambilan sampel dalam penelitian ini menggunakan metode Purposive sampling dengan pendekatan Kuota Sampling dengan setiap SKPD terdapat 3 responden yang menjadi sampel yaitu Kepala Bagian Keuangan, Kepala Seksi selaku reviewer laporan keuangan yang telah disusun dan Staf Bagian Akuntansi yang bertugas langsung menyusun laporan keuangan. Tekhnik analisa data yang digunakan dalam penelitian ini adalah Uji Validitas, Uji Reliabilitas, Uji Asumsi Klasik (Normalitas, Multikolinearitas, Autokorelasi) dan Uji Hipotesis dengan Uji Regresi Linear Berganda. Hasil analisis yang dilakukan dalam penelitian ini menunjukan bahwa terdapat pengaruh positif penerapan Standar Akuntansi Pemerintah dan Sistim Pengendalian Internal terhadap Kualitas Laporan Keuangan di Satuan Kerja Perangkat daerah Pemerintahan Kota Bima.
\end{abstract}

Kata Kunci : Standar Akuntansi Pemerintah, Sistim Pengendalian Internal, Kualitas Laporan Keuangan. 


\section{PENDAHULUAN}

Dalam Perkembangan ilmu pengetahuan dan tekhnologi yang sangat pesat ditandai dengan Revolusi Industri 4.0 penulis memandang bahwa untuk mewujudkan tata kelola pelaksanaan pemerintahan daerah yang baik (good governance), pemerintah daerah harus berusaha mewujudkan perbaikan kinerja di segala bidang, termasuk di bidang Informasi Keuangan atau Akuntansi yang berkaitan dengan transparansi dan akuntabilitas pengelolaan keuangan daerah.

Untuk mencapai pengelolaan keuangan pemerintaan daerah yang baik (Good Governance) sesuai yang diamanatkan UU No. 17 tahun 2003 pasal 3 ayat (1) menegenai ketentuan pengelolaan keuangan daerah, bahwa pada dasarnya pengelolaan keuangan Negara oleh pemerintah harus di kelola secara tertib dan taat pada peraturan perundangan-undangan, akuntabilitas bukan hanya kemampuan untuk menunjukan bagaimana uang kas negara di belanjakan melain kan kemampuan untuk menunjukan, efisiensi, ekonomis dan efektifitas serta transparansi penggunaan kas Negara dan bertanggung jawab dengan memperhatikan rasa keadilan dan kepatuhan.

Pengelolaan kas Negara baik dari transfer pemerintah pusat maupun dari masyarakat itu sendiri harus dilandasi semangat akuntabilitas dan transparansi sehingga pada akhirnya menciptakan laporan keuangan yang berkualitas sesuai dengan kriteria dan aturan yang berlaku serta dapat di pertanggungjawabkan kepada masyarakat. Dengan demikian pemerintah daerah dituntut untuk dapat menyajikan laporan keuangan yang berkualitas, untuk mencapai kualitas laporan keuangan yang baik tentu dalam proses penyusunan laporan keuangannya harus menerapkan Standard Akuntansi Pemerintah (SAP) yang ditetapkan dengan peraturan Pemerintah No.71 tahun 2010 sebagai pengganti Peraturan Pemerintah No.24 Tahun 2005. SAP dinyatakan dalam bentuk pernyataan standar Akuntansi Pemerintahan (PSAP), dilengkapi dengan pengantar standar Akuntansi Pemerintahan dan disusun dengan mengacu kepada kerangka konseptual Akuntansi Pemerintahan.

Didalam sistem pelaporan keuangan yang baik tentu terdapat pula Sistem Pengendalian Intern yang baik. Pemerintah menyadari betul hal tersebut. Karena itu di rancang sebagai sistem dan regulasi untuk menjaga kualitas tersebut. Sistim Pengendalian Internal merupakan hal penting yang tidak bisa diabaikan jika berbicara tentang kualitas laporan keuangan pemerintah daerah. Sistim Pengendalian Internal merupakan suatu cara untuk mengarahkan, mengawasi dan mengukur sumber daya suatu organisasi, dan juga memiliki peran penting dalam pencegahan dan pendeteksian penggelapan (fraud) secara dini. Sistim pengendalian Internal akan memandu organisasi berjalan sebagaimana semestinya.

Melalui Penguatan Sistem pengendalian Internal Pemerintah daerah diharapkan dan di upayakan perbaikan kualitas laporan keuangan dapat lebih di pacu untuk mencegah terjadinya kegiatan yang tidak sesuai ketentuan yang berlaku sehhingga pelaksanaan pemerintahan yang baik (Good Governance) dapat diwujudkan yang tercermin dari efisiensi, ekonomis, dan efektifitas pelaksanaan kegiatan, dan sistem pengendalian internal yang baik diharapkan mencegah terjadinya kerugian Negara. 
Dari Uraian diatas dan terlebih

belum pernah dilakukan sebelumnya penelitian tentang Kualitas Laporan Keuangan di pemerintahan Kota Bima, maka penulis tertarik untuk meneliti "Pengaruh Penerapan Stadar Akuntansi Pemerintah dan Sistim pengendalian Internal terhadap Kualitas Laporan Keuangan (Studi Kasus di SKPD pemerintahan Kota Bima)".

\section{TINJAUAN PUSTAKA}

\subsection{Teori Keagenan (Agency Thery)}

Teori Keagenan pada dasarnya merupakan teori yang muncul karena adanya konflik kepentingan antara principal dan agen. Teori ini mengasumsikan bahwa masing-masing individu semata-mata termotivasi oleh kepentingan dirinya sendiri sehingga menimbulkan konflik kepentingan antara prinsipal dan agen, prinsipal mengontrak agen untuk melakukan pengelolaan sumber daya dalam perusahaan dan berkewajiban untuk memberikan imbalan kepada agen sedangkan agen berkewajiban melakukan pengelolaan sumber daya yang dimiliki oleh perusahaan dan bertanggung jawab atas tugas yang dibebankan kepadanya (Jensen, M., dan W. Meckling, 1976).

Teori keagenan akan terjadi pada berbagai organisasi termasuk dalam organisasi pemerintahan dan berfokus pada persoalan ketimpangan/asimetri informasi antara pengelola (agen/pemerintah) dan publik (diwakili prinsipal/Dewan). Prinsipal harus memonitor kerja agen agar tujuan organisasi dapat dicapai dengan efisien serta tercapainya akuntabilitas publik. Praktek pelaporan Keuangan dalam organisasi sektor publik merupakan suatu konsep yang didasari oleh teori keagenan. Pemerintah yang bertindak sebagai agen mempunyai kewajiban menyajikan informasi yang bermanfaat bagi para pengguna informasi keuangan pemerintah yang bertindak sebagai prinsipal dalam menilai akuntabilitas dan membuat keputusan ekonomi, sosial, maupun politik, serta baik secara langsung melalui wakil-wakilnya (Irwan, 2010).

1. Hubungan keagenan dalam pengelolaan keuangan daerah

Keagenan dalam pengelolaan keuangan daerah diinterprestasikan dalam 2 (dua) hubungan yaitu :

a. Hubungan rakyat sebagai prinsipal dan kepala daerah sebagai agen, undangundang nomor 32 tahun 2004 tentang pemerintahan daerah menyatakan kepala daerah dipilih oleh rakyat. Mekanisme pemilihan ini merupakan pemberian otoritas eksekutif dan pelimpahan wewenang rakyat kepada pemerintah daerah (Gubernur, Walikota/Bupati). Pemerintah daerah juga menerima pelimpahan wewenang atas pengelolaan sumber daya yang ada didaerah. Pertanggung jawaban yang diberikan rakyat wajib memberikan laporan pertanggung jawaban atas perencanaan dan pelaksanaan pengelolaan sumber daya yang tertuang dalam APBD kepada rakyat dalam bentuk LKPD yang telah diaudit oleh BPK. DPRD yang merupakan representasi keterwakilan rakyat selaku prinsipal adalah pengemban fungsi kontrol terhadap jalanya pemerintahan didaerah.

b. Hubungan Kepala Daerah sebagai prinsipal dan kepala SKPD sebagai agen, tercermin dalam Permendagri Nomor 13 Tahun 2006 tentang pedoman pengelolaan keuangan daerah dilaksanakan oleh kepala SKPD selaku PPKD dan kepala SKPD selaku 
pejabat pengguna Anggaran, atau pengguna barang daerah. Kedudukan kepala SKPD dan PPKD adalah menerima wewenang dari kepala daerah selaku pemegang kekuasaan pengelolaan keuangan daerah, Kepala daerah selaku prinsipal wajib melaksanakan sistem kontrol melalui Sistim Pengendalian Intrenal untuk menjamin bahwa progam dan kegiatan yang tertuang dalam APBD serta penatausahaan atas pengelolaan keuangan daerah dapat dijalankan secara baik sehinga tujuan organisasi dapat dicapai. Kepala SKPD dan PPKD selaku agen wajib bertanggung jawab atas pelaksanaan wewenang yang telah diterimanya kepada kepala daerah melalui sekretaris daerah selaku koordinator pengelolaan keuangan daerah.

\subsection{Kualitas Laporan Keuangan}

Laporan keuangan menurut Kasmir dalam (Evicahyani \& Setiawina, 2016) merupakan alat akuntabilitas utama pemerintah kepada wakil rakyat di parlemen atau lembaga-lembaga negara lain yang berkepentingan serta masyarakat umum, sedangkan menurut (Mahmudi, 2011:43) Laporan keuangan merupakan output dari sistem akuntansi yang bermanfaat untuk pemberian informasi bagi pihak-pihak yang akan menjadikan informasi keuangan tersebut sebagi dasar pembuatan keputusan.

Laporan keuangan pada dasarnya merupakan asersi dari pihak manajemen pemerintah yang menginformasikan kepada pihak lain yaitu para pemangku kepentingan (stakeholder), tentang kondisi keuangan pemerintah di Indonesia. Laporan keuangan pokok yang harus dibuat oelh pemerintah sebagaimana tercantum dalam pasal 30
UU No. 17 Tahun 2003 tentang Keuangan Negara meliputi : (1) Laporan realisasi APBN/D (2) Neraca, (3) Laporan arus kas (4) Catatan atas Laporan Keuangan, dan (5) Lampiran laporan keuangan perusahaan Negara/daerah.

Kualitas (quality) merupakan konstruk yang penting dalam dunia bisnis, pendidikan dan berkaitan dengan orang banyak. Didalam penelitian akuntansi, kualitas harus dikonseptualisasikan dengan suatu definisi operasional sehingga dapat diukur dengan suatu instrument yang diciptakan untuk keperluan tersebut. (Adha Inapty \& Martiningsih, 2016) bahwa kualitas merupakan suatu kondisi dinamis yang berhubungan dengan produk jasa, manusia, proses dan lingkungan yang memenuhi atau melebihi harapan. Sedangkan Parasuraman (Sako \& Lantowa, 2018) mengemukakan bahwa kualitas merupakan ukuran penilaian menyeluruh atas tingkat suatu pelayanan .

Dengan memperhatikan pentingnya kualitas maka dalam konteks laporan keuangan, kualitas juga merupakan salah satu indikator penting. Kualitas menjadi suatu ukuran apakah laporan keuangan tersebut wajar dan sesuai dengan standar dan kaidah - kaidah yang telah sepakati untuk diterima secara umum.

\subsection{Standar Akuntansi Pemerintah}

Definisi Standar Akuntansi Pemerintah menurut (Nugraeni, 2012) menyatakan bahwa Standar Akuntansi Pemerintah, selanjutnya disebut SAP, adalah prinsip-prinsip akuntansi yang diterapkan dalam menyusun dan menyajikan laporan keuangan pemerintah. Dengan demikian SAP merupakan persyaratan yang mempunyai kekuatan Hukum dalam upaya meningkatkan kualitas laporan keuangan di pemerintahan di Indonesia. Peraturan 
Pemerintah RI nomor 24 tahun 2005 dijelaskan bahwa karakteristik kualitatif laporan keuangan adalah ukuran-ukuran normatif yang perlu diwujudkan dalam informasi akuntansi sehingga dapat memenuhi tujuannya. Keempat karakteristik berikut ini merupakan syarat normatif yang diperlukan agar laporan keuangan pemerintah dapat memenuhi kualitas yang dikehendaki yaitu Relevan, Andal, Dapat di Bandingkan, dan mudah dipahami.

\subsection{Sistim Pengendalian Internal}

Menurut Peraturan Pemerintah No. 60 tahun 2008 dalam (Yuliani \& Agustini, 2016) Sistem Pengendalian Internal adalah proses yang tidak terpisahkan pada kegiatan organisasi yang dilakukan secara terus-menerus oleh pimpinan dan seluruh pegawai untuk keyakinan memadai atas tercapainya tujuan organisasi melalui kegiatan yang efektif dan efisien, keandalan pelaporan keuangan, pengamanan asset Negara dan ketaatan terhadap peraturan undangundangan.

Unsur Sistim Pengendalian Internal yang berfungsi sebagai pedoman penyelenggaraan dan tolak ukur pengujian efektivitas penyelenggaraan sistim pengendalian internal. Pengembangan Unsur Sistim Pengendalian Internal perlu mempertimbangkan aspek biaya manfaat (Cost and Benefit), Sumber daya Manusia, kejelasan kriteria pengukuran dan perkembangan tekhnologi Informasi serta dilakukan secara konperhensih.

Menurut Pemerintah No. 60 tahun 2008 dalam (Rama Mahaputra \& Putra, 2014) bahwa unsur Sistim Pengendalian Internal dalam peraturan pemerintah ini mengacu pada unsur sistim pengendalian yang telah di praktikan dilingkungan pemerintah di berbagai Negara, yang meliputi : Lingkungan Pengendalian, Penilaian Risiko, kegiatan pengendalian, Informasi dan komunikasi pemantauan.

\section{METODE PENELITIAN}

Jenis penelitian ini adalah penelitian Kuantitatif, dalam penelitian ini terdiri dari dua Variabel independen yaitu Standar Akuntansi Pemerintah Daerah dan Sistim Pengendalian Internal, serta satu variabel dependen yaitu Kualitas Laporan Keuangan. Yang menjadi Populasi atau objek analisis dalam penelitian ini adalah Satuan Kerja Perangkat Daerah sebagai entitas akuntansi di wilaya pemerintahan Kota Bima.

Metode pengambilan sampel dalam penelitian ini menggunakan metode Purposive sampling dengan pendekatan Kuota Sampling dengan setiap SKPD terdapat 3 responden yang menjadi sampel yaitu Kepala Bagian Keuangan, Kepala Seksi selaku reviewer laporan keuangan yang telah disusun dan Staf Bagian Akuntansi yang bertugas langsung menyusun laporan keuangan, Instrumen penelitian yang digunakan adalah dengan cara membagikan Kuesioner. Tekhnik analisa data yang digunakan adalah Regresi Linear Berganda.

\subsection{Kerangka Konseptual Penelitian}

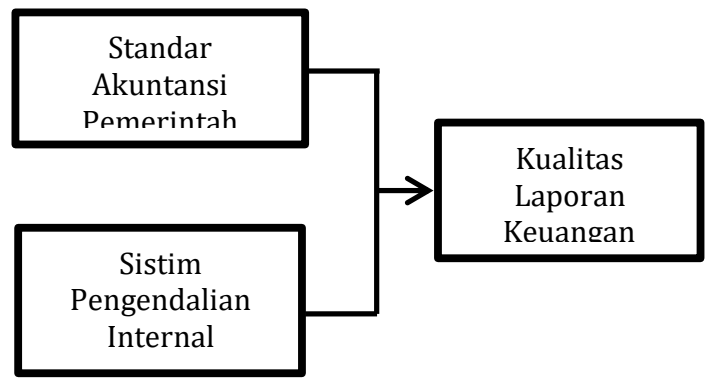

Gambar 1. Kerangka Konseptual Penelitian 


\subsection{Pengembangan Hipotesis}

\section{a. Standar Akuntansi Pemerintah Berpengaruh positif Terhadap Kualitas Laporan Keuangan.}

Menurut Peraturan pemerintah dalam (Singkali \& Widuri, 2014) Standar Akuntansi Pemerintahan adalah prinsipprinsip Akuntansi yang diterapkan dalam menyusun dan menyajikan laporan keuangan pemerintah yang ditetapkan dengan peraturan pemerintah No. 24 Tahun 2005 tanggal 13 Juni 2005. Dalam PP No.24 Tahun 2005 Pasal 1 (5) juga disebutkan Standar Akuntansi Pemerintah adalah serangkaian prosedur manual maupun yang terkomputerisasi mulai dari pengumpulan data, pencatatan, pengikhtisaran dan pelaporan posisi keuangan dan operasi keuangan pemerintah.

Karakteristik kualitatif laporan keuangan adalah ukuran-ukuran nor matif yang perlu diwujudkan dalam informasi akuntansi sehingga dapat memenuhi tujuannya. Menurut Peraturan Menteri Dalam Negeri Nomor 13 Tahun 2006, keempat karakteristik berikut ini merupakan prasyarat normatif yang diperlukan agar laporan keuangan pemerintah dapat memenuhi kualitas yang dikehendaki : Relevan, Andal, Dapat di Bandingkan, dan Dapat Dipahami ( oka reza Aditya \& Surjono, 2017).

Agar bisa menghasilkan Suatu Laporan Keuangan Pemerintahan daerah yang berkualitas diperlukan proses tahapan yang harus dilalui yang diatur dalam Standar Akuntansi Pemerintah Daerah, maka dari itu Standar Akuntansi Pemerintah perlu diterapkan dengan baik untuk menghasilkan Informasi Akuntansi yang berkualitas yang tersaji dalam Laporan Keuangan. Dalam
Penelitian yang pernah dilakukan oleh (Neneng Sri Suprihatin, 2019) menunjukan hasik bahwa Standar Akuntansi Pemerintah Berpengaruh Positif dan signifikan terhadap Kualitas Laporan Keuangan.

\section{H1: Standar Akuntansi Pemerintah Berpengaruh positif Terhadap Kualitas Laporan Keuangan.}

\section{b. Sistim Pengendalian Internal Berpengaruh Positif terhadap Kualitas Laporan Keuangan}

Sistem Pengendalian Intern merupakan proses yang integral pada setiap tindakan dan kegiatan yang dilakukan secara terus menerus oleh jajaran pimpinan dan seluruh pegawai yang ada di Satuan kerja perangkat daerah setiap pemerintahan agar bisa mengahasilkan suatu Laporan Keuangan yang berkualitas untuk memberikan keyakinan memadai atas tercapainya tujuan organisasi melalui kegiatan yang efektif dan efisien, keandalan pelaporan keuangan, pengamanan asset negara dan ketaatan terhadap peraturan perundangundangan. Penelitian yang pernah dilakukan oleh (Rokhlinasari \& Hidayat, 2016) dan penelitian lain juga yang pernah dilakukan oleh (Pranata, 2019) menjelaskan bahwa Sistim Pengendalian Internal berpengaruh Positif terhadap Kualitas Laporan Keuangan.

\section{H2 : Sistim Pengendalian Internal Berpengaruh Positif Terhadap Kualitas Laporan Keuangan}




\section{HASIL DAN PEMBAHASAN}

\subsection{Hasil Uji Instrumen Penelitian Validitas dan Reliabilitas}

Tabel 1. Hasil Pengujian Validilitas Standar Akuntansi Pemerintahan

\begin{tabular}{ccccc}
\hline $\begin{array}{c}\text { Butir } \\
\text { Pertanyaan }\end{array}$ & r Hitung & r Tabel & Kriteria & Keterangan \\
\hline SAP_1 & 0.367 & 0.2162 & r hitung $>$ r tabel & Valid \\
SAP_2 & 0.480 & 0.2162 & r hitung $>$ r tabel & Valid \\
SAP_3 & 0.573 & 0.2162 & r hitung $>$ r tabel & Valid \\
SAP_4 & 0.410 & 0.2162 & r hitung $>$ r tabel & Valid \\
SAP_5 & 0.478 & 0.2162 & r hitung $>$ r tabel & Valid \\
SAP_6 & 0.673 & 0.2162 & r hitung $>$ r tabel & Valid \\
SAP_7 & 0.658 & 0.2162 & r hitung $>$ r tabel & Valid \\
SAP_8 & 0.645 & 0.2162 & r hitung $>$ r tabel & Valid \\
\hline
\end{tabular}

Tabel 2. Hasil Pengujian Validilitas Sistim Pengendalian Internal

\begin{tabular}{ccccc}
\hline $\begin{array}{c}\text { Butir } \\
\text { Pertanyaan }\end{array}$ & r Hitung & r Tabel & Kriteria & Keterangan \\
\hline SPI_1 & 0.780 & 0.2162 & $r$ hitung $>r$ tabel & Valid \\
SPI_2 & 0.710 & 0.2162 & $r$ hitung $>r$ tabel & Valid \\
SPI_3 & 0.744 & 0.2162 & $r$ hitung $>r$ tabel & Valid \\
SPI_4 & 0.766 & 0.2162 & $r$ hitung $>r$ tabel & Valid \\
SPI_5 & 0.757 & 0.2162 & $r$ hitung $>r$ tabel & Valid \\
SPI_6 & 0.713 & 0.2162 & $r$ hitung $>r$ tabel & Valid \\
SPI_7 & 0.695 & 0.2162 & $r$ hitung $>r$ tabel & Valid \\
SPI_8 & 0.601 & 0.2162 & $r$ hitung $>r$ tabel & Valid \\
SPI_9 & 0.840 & 0.2162 & $r$ hitung $>r$ tabel & Valid \\
SPI_10 & 0.808 & 0.2162 & $r$ hitung $>r$ tabel & Valid \\
SPI_11 & 0.659 & 0.2162 & $r$ hitung $>r$ tabel & Valid \\
\hline
\end{tabular}

Tabel 3. Hasil Pengujian Validilitas Kualitas Laporan Keuangan

\begin{tabular}{ccccc}
\hline $\begin{array}{c}\text { Butir } \\
\text { Pertanyaan }\end{array}$ & r Hitung & r Tabel & Kriteria & Keterangan \\
\hline KLK_1 & 0.683 & 0.2162 & $r$ hitung $>r$ tabel & Valid \\
KLK_2 & 0.636 & 0.2162 & $r$ hitung $>r$ tabel & Valid \\
KLK_3 & 0.677 & 0.2162 & $r$ hitung $>r$ tabel & Valid \\
KLK_4 & 0.657 & 0.2162 & $r$ hitung $>r$ tabel & Valid \\
KLK_5 & 0.733 & 0.2162 & $r$ hitung $>r$ tabel & Valid \\
KLK_6 & 0.690 & 0.2162 & $r$ hitung $>r$ tabel & Valid \\
KLK_7 & 0.708 & 0.2162 & $r$ hitung $>r$ tabel & Valid \\
KLK_8 & 0.680 & 0.2162 & $r$ hitung $>r$ tabel & Valid \\
KLK_9 & 0.544 & 0.2162 & $r$ hitung $>r$ tabel & Valid \\
KLK_10 & 0.696 & 0.2162 & $r$ hitung $>r$ tabel & Valid \\
\hline
\end{tabular}




\section{Tabel 4. Hasil Pengujian Reliabilitas}

\begin{tabular}{lccc}
\hline \multicolumn{1}{c}{ Butir Pertanyaan } & $\begin{array}{c}\text { Cronbach's } \\
\text { Alpha }\end{array}$ & Kriteria & \multirow{2}{*}{ Keterangan } \\
\hline Standar Akuntansi Pemerintah & 0.632 & Cronbach's Alpha $>0.60$ & Reliabel \\
Sistim pengendalian Internal & 0.911 & Cronbach's Alpha $>0.60$ & Reliabel \\
Kualitas Laporan Keuangan & 0.863 & Cronbach's Alpha $>0.60$ & Reliabel \\
\hline
\end{tabular}

\section{Hasil Uji Asumsi Klasik}

Tabel 5. Hasil Uji Normalitas

\begin{tabular}{cccc}
\hline $\mathbf{N}$ & Asymp Sig & Kriteria & Keterangan \\
\hline 57 & 0.810 & $>0,05$ & Data Berdistribusi Normal \\
\hline
\end{tabular}

Tabel 6. Hasil Uji Multikolinearitas

\begin{tabular}{lccccc}
\hline \multicolumn{1}{c}{ Variabel } & Tolerance & Kriteria & VIF & $\begin{array}{c}\text { Kriteri } \\
\mathbf{a}\end{array}$ & Keterangan \\
\hline $\begin{array}{l}\text { Standart Akuntansi } \\
\text { Pemerintahan }\end{array}$ & 0.637 & $>0,10$ & 1.570 & $<10$ & $\begin{array}{c}\text { Tidak Terjadi } \\
\text { Multikolinearitas }\end{array}$ \\
Sistim Pengendalian Internal & 0.637 & $>0,10$ & 1.570 & $<10$ & $\begin{array}{c}\text { Tidak Terjadi } \\
\text { Multikolinearitas }\end{array}$ \\
\hline
\end{tabular}

Tabel 7. Hasil Uji Autokorelasi

\begin{tabular}{ccccc}
\hline DW & dL & dU & 4-dU & Keterangan \\
\hline 1.740 & 1.6452 & 1.5004 & 2.4996 & Tidak Terjadi Gejala Autokorelasi \\
\hline
\end{tabular}

\section{Uji Regresi Linear Berganda}

Tabel 8. Hasil Uji Hipotesis Secacara Parsial ( Uji_t )

\begin{tabular}{lccccc}
\hline \multicolumn{1}{c}{ Variabel } & t hitung & t tabel & Kriteria & Sig & Kesimpulan \\
\hline $\begin{array}{l}\text { Standar Akuntansi } \\
\begin{array}{l}\text { Pemerintah } \\
\text { Sistim pengendalian }\end{array}\end{array}$ & 2.115 & 1.673 & t hitung $>$ t tabel & 0.039 & H1 Diterima \\
Internal & 6.570 & 1.673 & t hitung $>$ t tabel & 0.000 & H2 Diterima \\
\hline
\end{tabular}

Tabel 9. Hasil Uji Hipotesis Secara Simultan (Uji_F)

\begin{tabular}{ccccc}
\hline F Hitung & F Tabel & Kriteria & Sig & Kesimpulan \\
\hline 50.517 & & F Hitung $>$ F Tabel & 0.000 & Layak \\
\hline
\end{tabular}

Tabel 10. Hasil Uji Koefisien Determinasi (Adjusted $\mathbf{R}^{2}$ )

\begin{tabular}{cc}
\hline Adjusted R Square & Keterangan \\
\hline 0.639 & $\begin{array}{c}\text { Besarnya Pengaruh variabel Independen } \\
\text { dalam model regresi sebesar } 63.90 \%\end{array}$ \\
\hline
\end{tabular}




\subsection{Standar Akuntansi Pemerintah berpengaruh positif terhadap kualitas laporan Keuangan (H1)}

Dari Hasil yang di tampilkan pada tabel 8 dapat di tarik kesimpulan bahwa Standar Akuntansi Pemerintah berpengaruh positif terhadap Kualitas Laporan Keuangan SKPD yang ada di pemerintahan Kota Bima. Hasil penelitian ini di dukung oleh penelitian sebelumnya yang di lakukan oleh (Efrianti et al., 2018)

Penerapan Standar Akuntansi Pemerintah dengan baik dan tepat akan mempermudah dan membantu SKPD sebagai Agen untuk memberikan Laporan Pertanggung jawaban kepada masyarakat sebagai Prinsipal atas kepercayaan yang di amanatkan kepada mereka untuk mengelola kekayaan dan asset daerah untuk kemaslahatan Masyarakat. Untuk itu sangat penting Bagi pemangku Jabatan yang ada di jajaran SKPD pemerintahan Kota Bima memberikan atau mengikut sertakan Pegawainya untuk melakukan pelatihan guna meningkatkankan wawasan dan pengetahuan Pegawai terhadap Standar Akuntansi Pemerintah.

\subsection{Sistim pengendalian Internal berpengaruh positif terhadap Kualitas Laporan Keuangan (H2)}

Dari hasil analisis yang ditampilkan pada tabel 8 dapat di tarik kesimpulan bahwa Sistim Pengendalian Internal berpengaruh positif dan signifikan terhadap Kualitas Laporan Keuangan. Hasil penelitian ini di dukung juga oleh penelitian sebelumnya yang pernah di lakukan oleh (Widari \& Sutrisno, 2017) dan Juga Penelitian yang dilakukan oleh (O. R. Aditya \& Surjono, 2017),

Hasil penelitiannya menunjukkan bahwa Sistim Pengendalian Internal berpengaruh positif terhadap Kualitas Laporan Keuangan. Untuk Menghasilkan dan Juga Penelitian yang dilakukan oleh (Nugraeni, 2012) , Hasil penelitiannya menunjukkan bahwa Standar Akuntansi Pemerintah berpengaruh positif terhadap Kualitas Laporan Keuangan. Semakin baik pemahaman Pegawai terahadap Standar Akuntansi Pemerintah maka akan semakin baik pula Kualitas Laporan Keuangan yang ada di Lingkup Pemerintahan Daerah tersebut.

Suatu Laporan keuangan yang baik diperlukan juga Sistim pengendalian Internal yang baik pula, dengan adanya sistim pengendalian internal dalam organisasi pemerintahan akan dapat meningkatkan ketelitian dan keandalan pencatatan data Akuntansi, dan Sistim pengendalian Internal Akuntansi yang baik dapat meminimalisir risiko terjadinya kekeliruan dan kesalahan pencatatan atau perhitungan, suatu sistim pengendalian internal yang berkualitas dapat diterapkan dengan baik apabila bagian-bagian yang terkait dengan sistim tersebut beroperasi sesuai dengan tugas dan tanggung jawabnya masing-masing.

Dengan ditetapkannya pengendalian internal dalam sistim Akuntansi, maka kualitas informasi laporan Keuangan yang dihasilkan oleh SKPD yang ada di pemerintahan Kota Bima akan menjadi lebih berkualitas (Relevan, Andal, dan dapat dipahami, tepat waktu, Akurat, dan lengkap) dan akan membantu mempermudah pada saat laporan keuangan tersebut di Audit. 


\section{PENUTUP}

Setelah melakukan serangkaian analisis Statistik antara lain Uji Validitas dan Uji Reliabilitas di peroleh kesimpulan bahwa butir pertanyaan dalam kuesioner yang di bagikan untuk mengukur variabelvariabel yang di teliti dinyatakan Valid dan Reliabel. Berikutnya Analisis Korelasi menunjukan variabel Standar Akuntansi Pemerintah dan Sistim Pengendalian Internal berkorelasi Positif dan signifikan terhadap Kualitas Laporan Keuangan. Dan dari hasil Koefisien determinasi menunjukkan bahwa besaran persentase kontribusi dari variabel independen terhadap kualitas Laporan Keuangan sebesar 63,90\% dan sisanya sebesar $36,10 \%$ di pengaruhi oleh variabel lain yang tidak di masukkan kedalam model penelitian ini.

Hasil dari penelitian ini mengindikasikan bahwa Satuan Kerja Perangkat Daerah di Pemerintahan Kota Bima telah menerapkan dengan Baik Standar Akuntansi Pemerintah dan telah melakukan Pengendalian Internal yang sangat Baik di jajaran Instansi Pemerintahan guna Meningkatkan Kualitas Laporan Keuangan sebagai bentuk

\section{DAFTAR PUSTAKA}

Adha Inapty, M. A. F. B., \& Martiningsih, R. S. P. (2016). Pengaruh Penerapan Standar Akuntansi Pemerintah, Kompetensi Aparatur Dan Peran Audit Internal Terhadap Kualitas Informasi Laporan Keuangan Dengan Sistem Pengendalian Intern Sebagai Variabel Moderating (Studi Empiris Pada Skpd Di Pemprov Ntb). Akuntabilitas, 9(1), 27-42.

Https://Doi.Org/10.15408/Akt.V9i1.35 83

Aditya, Oka Reza, \& Surjono, W. (2017). Sistem Informasi, Keuangan, Auditing Dan Perpajakan. Sikap, 2(1), 1-14.
Akuntabilitas dan Tansparansi pengelolaan keuangan daerah kepada Masyarakat.

Dalam penelitian ini, dengan kerendahan hati penulis menyadari betul bahwa masih terdapat beberapa keterbatasan antara lain hasil penelitian ini menunjukan bahwa determinasi variabel independen terhadap variabel dependen sebesar 63,90\%, Untuk itu saran bagi peneliti berikutnya dapat memperkaya lagi objek penelitian dengan menambahkan beberapa variabel lain seperti Akuntabilitas, Kualitas Aparatur Daerah, dan Penerapan Tekhnologi Informasi, dan sebaiknya Untuk bisa mencangkup Populasi dan sampel yang lebih luas lagi.

Untuk Kepala Daerah Pemerintahan Kota Bima sendiri Penulis menyarankan untuk bisa memberikan pelatihan secara rutin guna meningkatkan pengetahuan dan pemahaman bagi Aparatur Pegawai Daerah dalam penyusunan Laporan Keuangan Daerah, serta mempertahankan dan meningkatkan lagi sistim pengendalian internal yang ada di jajaran internal Satuan kerja Perangkat daerah di pemerintahan Kota Bima.

Aditya, O. R., \& Surjono, W. (2017). Pengaruh Sistem Pengendalian Intern Terhadap Kualitas Laporan Keuangan. Jurnal Sikap (Sistem Informasi, Keuangan, Auditing Dan Perpajakan), 2(1), Https://Doi.Org/10.32897/Sikap.V2i1.6 4

Efrianti, D., Tinggi, S., \& Ekonomi, I. (2018). Analisis Penerapan Standar Akuntansi Pemerintah ( Sap ) Terhadap Kualitas Laporan Keuangan Instansi Pemerintah Pada Kantor Pusat Pelatihan Manajemen Dan Kepemimpinan Pertan .... September.

Evicahyani, S. I., \& Setiawina, N. D. (2016). Analisis Faktor-Faktor Yang 
Mempengaruhi Kualitas Laporan Keuangan Pemerintah Daerah Kabupaten Tabanan. E-Jurnal Ekonomi Dan Bisnis Universitas Udayana, 5(3), 403-428.

Irwan Taufiq. (2010). Akuntansi Pemerintah Daerah. Yogyakarta Sekolah Pasca Sarjana Ugm.

Jensen, M., C., W. M. (1976). No Title. In Journal of Finance Economic. Http://Www.Nhh.No/For/Courses/Sprin g/Eco420/Jensen-Meckling-76.Pdf.

Mahmudi. (2011). Akuntansi Sektor Publik. Yogyakarta, Uii Press.

Neneng Sri Suprihatin, A. A. A. (2019). Pengaruh Penerapan Sistem Informasi Akuntansi Terhadap Kualitas Laporan Keuangan. Jurnal Akuntansi, 12(2), 242-252.

Https://Doi.Org/10.37932/Ja.V9i1.94

Nugraeni, M. B. (2012). Pengaruh Standar Akuntansi Pemerintah Terhadap Universitas Mercu Buana Yogyakarta. Jurnal Dinamika Ekonomi Dan Bisnis, 12(1), 18-32.

Pranata, V. M. (2019). Pengaruh Pengendalian Internal Dan Komitmen Organisasi Terhadap Kualitas Pelaporan Keuangan ( Survei Pada Perusahaan Tekstil Di Kota Bandung Dan Sekitarnya ). 1, 15-30.

Rama Mahaputra, I., \& Putra, I. (2014). Analisis Faktor-Faktor Yang Mempengaruhi Kualitas Informasi Laporan Keuangan Pemerintah Daerah. E-Jurnal Akuntansi, 8(2), 230-244. Https://Doi.Org/10.15294/Jda.V7i2.412 4

Rokhlinasari, S., \& Hidayat, A. (2016). AlAmwal, Volume 8, No. 2 Tahun 2016. Pengaruh Sistem Pengendalian Internal Terhadap Kualitas Laporan Keuangan Pada Ban Bjb Syariah Cirebon, 8(2), 491-508.

Sako, U., \& Lantowa, F. D. (2018). Pengaruh Penerapan Standar Akuntansi Pemerintahan Terhadap Kualitas Penyajian Laporan Keuangan Pada Pemerintah Kabupaten Gorontalo.
Journal Of Accounting Science, 2(1), 43.

Https://Doi.Org/10.21070/Jas.V2i1.110 1

Singkali, O. Y. F., \& Widuri, R. (2014). Dinas Pendapatan Dan Pengelolaan Keuangan Aset Daerah (Dppkad) Kabupaten Toraja Utara. Tax \& Accounting Review, 4(2), 1-15.

Widari, L., \& Sutrisno. (2017). Pengaruh Sistem Pengendalian Internal Pemerintah Dan Komitmen Organisasi Terhadap Kualitas Laporan Keuangan Daerah. Jurnal Ilmiah Ilmu Ekonomi, 5(10), 117-126.

Yuliani, N. L., \& Agustini, R. D. (2016). Faktor Yang Mempengaruhi Kualitas Laporan Keuangan Pemerintah Daerah. Bisnis \& Ekonomi, 14(1), 56-64. 